\title{
ANALISIS TRIWULANAN: \\ Perkembangan Moneter, Perbankan dan Sistem Pembayaran, Triwulan IV - 2010
}

\author{
Tim Penulis Laporan Triwulanan, Bank Indonesia
}

Perekonomian Indonesia di tahun 2010 menunjukkan akselerasi pertumbuhan yang cukup tinggi di tengah ketidakseimbangan pemulihan ekonomi global. Perekonomian domestik diprakirakan dapat tumbuh 6,1\% pada triwulan IV-2010 sehingga untuk keseluruhan tahun 2010 perekonomian nasional dapat tumbuh sekitar 6\%. Untuk tahun 2011 dan 2012, Bank Indonesia optimis bahwa pemulihan ekonomi domestik akan semakin kuat ditopang oleh peningkatan permintaan domestik dengan kinerja investasi yang semakin baik. Perekonomian Indonesia di tahun 2011 diprakirakan tumbuh mencapai kisaran 6,0-6,5\% dan pada tahun 2012 menjadi 6,1-6,6\%.

Bank Indonesia mencatat bahwa proses pemulihan ekonomi global sepanjang tahun 2010 terus berlanjut meskipun cenderung melambat memasuki paruh kedua 2010 dan dengan kecepatan yang tidak merata di berbagai kawasan. Pemulihan ekonomi negara-negara emerging markets lebih kuat dibandingkan negara maju, didukung oleh konsumsi domestik yang solid dan kinerja eksternal yang terus membaik. Sementara itu, perekonomian negara maju yang membaik pada paruh pertama 2010, tumbuh melambat di paruh kedua tahun ini seiring memudarnya efek stimulus fiskal yang diluncurkan tahun 2009. Selain itu, pertumbuhan ekonomi negara maju juga dihadapkan pada krisis fiskal pada sejumlah negara Eropa dan tingginya angka pengangguran Amerika Serikat (AS).

Ketidakseimbangan pertumbuhan ekonomi ini berdampak pada perbedaan respons kebijakan moneter yang ditempuh. Bank sentral negara maju terus melanjutkan kebijakan akomodatif yang berdampak pada meningkatnya likuiditas global. Sementara itu, bank sentral negara emerging markets melakukan normalisasi kebijakan untuk menahan tekanan inflasi yang meningkat seiring akselerasi pemulihan ekonominya. Kondisi ini berdampak pada penguatan nilai tukar sejumlah negara emerging markets, termasuk Indonesia, yang kemudian direspons dengan menggunakan berbagai kombinasi instrumen kebijakan.

Kinerja pasar keuangan global mengalami rebound setelah keputusan negara-negara maju untuk mempertahankan kebijakan moneter yang akomodatif. Krisis fiskal yang melanda 
negara-negara Eropa (PIIGS-Portugal, Ireland, Italy, Greek, Spain) telah menurunkan risk appetite investor global. Hal ini mendorong investor untuk mengalihkan aset yang dinilai berisiko termasuk aset negara-negara emerging markets sehingga menimbulkan tekanan pada pasar keuangan global. Namun demikian, tekanan di pasar keuangan mulai mereda dan berangsur-angsur pulih pada paruh kedua 2010. Sinyal kebijakan moneter negara maju yang mempertahankan suku bunga rendah dan disertai paket stimulus moneter telah mendorong rally pada bursa saham global termasuk di emerging markets.

Dinamika yang terjadi pada perekonomian global sepanjang tahun 2010 telah memberikan pengaruh pada perkembangan ekonomi Indonesia. Pemulihan ekonomi global yang terus berlanjut khususnya di negara-negara emerging markets dan terjaganya stabilitas perekonomian telah memberikan dampak positif bagi akselerasi pertumbuhan ekonomi domestik. Kebijakan ekonomi makro yang dilakukan telah memberikan kontribusi bagi terpeliharanya keseimbangan internal dan eksternal dalam perekonomian Indonesia. Hal tersebut menjadi faktor penting untuk mendorong pertumbuhan ekonomi yang berkelanjutan. Pertumbuhan ekonomi domestik tahun ini ditopang oleh sumber pertumbuhan yang semakin seimbang tercermin pada kuatnya konsumsi dan tingginya permintaan ekspor serta investasi yang membaik. Konsumsi yang meningkat terutama berasal dari konsumsi rumah tangga sementara konsumsi pemerintah masih relatif terbatas seiring penyerapan anggaran yang masih terbatas. Di sisi ekspor, terjadi peningkatan kinerja pada tahun 2010 didukung oleh meningkatnya permintaan eksternal seiring pemulihan ekonomi global khususnya di kawasan Asia. Membaiknya kinerja ekspor juga didorong oleh peningkatan harga komoditas global. Sementara itu, kinerja investasi juga terus menunjukkan perbaikan didukung oleh membaiknya persepsi pasar, meningkatnya pembiayaan, relatif rendahnya harga barang impor, dan penerapan berbagai kebijakan pemerintah yang mendukung investasi.

Dari sisi penawaran, sektor nontradable dan sektor tradable menunjukkan kinerja yang membaik di tahun 2010. Pertumbuhan sektor tradable terutama berasal dari pulihnya sektor industri pengolahan yang mencapai tingkat pertumbuhan sebelum krisis keuangan global yakni sekitar 4\%. Namun, membaiknya kinerja sektor industri ini tidak diikuti oleh kinerja sektor tradable lainnya. Sektor pertanian tumbuh melambat dipengaruhi produktivitas serta luas lahan yang menurun dengan adanya anomali cuaca. Sementara, sektor pertambangan juga mengalami gangguan yang terkait faktor cuaca. Di sisi nontradable, pertumbuhan terutama berasal dari sektor perdagangan, hotel dan restoran, dan sektor pengangkutan dan komunikasi. Sementara itu, sektor nontradable lainnya cenderung melambat.

Di sisi harga, tahun 2010 diwarnai oleh tekanan inflasi yang cenderung meningkat, yang terutama bersumber dari kelompok volatile food. Tingginya tekanan inflasi dari kelompok bahan 
makanan (volatile food) disebabkan anomali cuaca yang mengakibatkan gangguan distribusi dan produksi. Tekanan inflasi yang bersumber dari kelompok administered pricesjuga meningkat meskipun terbatas. Kenaikan Tarif Dasar Listrik (TDL) di bulan Juli 2010 tidak mendorong kenaikan harga komoditas secara signifikan. Tekanan inflasi inti mengalami peningkatan meskipun masih terkendali seiring nilai tukar rupiah yang menguat. Peningkatan inflasi ini berasal dari tren peningkatan harga komoditas pasar global. Sementara itu, ekspektasi inflasi juga sempat meningkat dipengaruhi oleh kenaikan pada harga bahan makanan. Dengan perkembangan tersebut, sampai dengan November 2010 inflasi IHK tercatat sebesar 6,33(yoy) atau mencapai 5,98\% (ytd), sementara inflasi inti mencapai 4,31\%(yoy) atau 3,89\%(ytd).

Pemulihan ekonomi Indonesia yang terus membaik selama tahun 2010 tersebut juga terkonfirmasi oleh hasil asesmen perekonomian daerah yang dilakukan Bank Indonesia. Secara umum, perekonomian daerah selama tahun 2010 masih terus terakselerasi ditopang oleh kuatnya konsumsi, ekspor dan investasi. Wilayah Sumatera, Sulawesi, Kalimantan dan Papua diprakirakan mengalami peningkatan pertumbuhan ekonomi yang bersumber dari membaiknya kinerja perkebunan yang dipengaruhi oleh harga yang membaik. Sementara itu, kinerja sektor pertambangan yang banyak beroperasi di wilayah tersebut diprakirakan masih terbatas akibat anomali cuaca dan gangguan teknis produksi. Di wilayah Jakarta, Jawa, Bali, Nusa Tenggara, dan Kalimantan diprakirakan masih mengalami pertumbuhan yang cukup tinggi didukung oleh kinerja industri pengolahan dan sektor bangunan. Kegiatan investasi bangunan yang tumbuh cukup tinggi terjadi di Jakarta dan di wilayah Jawa, Bali, dan Nusa Tenggara.

Di sisi Neraca Pembayaran, pertumbuhan ekspor yang tetap kuat serta aliran modal masuk, baik dalam bentuk Penanaman Modal Asing (PMA) maupun portfolio yang masih kuat membawa dampak pada peningkatan surplus Neraca Pembayaran Indonesia. Pemulihan ekonomi global yang terus berlangsung terutama di negara-negara emerging markets telah mendorong kuatnya pertumbuhan ekspor. Peningkatan harga komoditas global juga turut mendorong perbaikan ekpor Indonesia dengan pangsa komoditas berbasis sumber daya alam (SDA) yang semakin besar. Di sisi lain, peningkatan ekonomi domestik dan apresiasi nilai tukar telah mendorong peningkatan impor yang lebih besar. Sementara itu, pemulihan ekonomi global yang tidak seimbang telah mendorong peningkatan yang besar pada aliran masuk modal asing. Secara keseluruhan, Neraca Pembayaran Indonesia pada tahun 2010 mencatat surplus yang meningkat dibandingkan tahun sebelumnya. Sejalan dengan perkembangan NPI tersebut, cadangan devisa Indonesia sampai dengan akhir November 2010 tercatat sebesar USD 92,759 miliar atau setara dengan 6,96 bulan impor dan pembayaran Utang Luar Negeri (ULN) pemerintah.

Nilai tukar rupiah menguat secara signifikan di tahun 2010. Penguatan rupiah didukung oleh faktor fundamental yang solid tercermin pada kinerja neraca transaksi berjalan yang 
mencatat surplus signifikan. Di samping itu, penguatan rupiah tersebut juga derasnya arus modal masuk asing terkait dengan melimpahnya likuiditas global, kuatnya ekspektasi berlanjutnya kebijakan suku bunga rendah di negara-negara maju dan peluncuran Quantitave Easing tahap II oleh The Fed. Derasnya aliran masuk modal asing juga didorong oleh terjaganya persepsi risiko dan sentimen positif sejalan dengan stabilitas makro dan sistem keuangan yang terkendali, pertumbuhan ekonomi yang tinggi, dan sustainabilitas fiskal yang terjaga. Dengan kondisi tersebut, sepanjang tahun 2010 nilai tukar rupiah telah terapresiasi secara rata-rata sebesar 3,7\% (y-t-d) atau menguat 4,3\% (p-t-p) dibandingkan tahun 2009. Penguatan tersebut diikuti juga oleh tingkat volatilitas tahunan yang turun menjadi 0,4\% dari sebelumnya 0,9\%.

Pasar keuangan domestik menunjukkan perkembangan yang terus membaik di tahun 2010 seiring dengan perkembangan perekonomian yang terus terakselerasi. Transmisi kebijakan moneter juga membaik sebagaimana tercermin pada respons suku bunga pasar uang dan perbankan yang terus menurun, serta ekspansi kredit yang meningkat. Di pasar obligasi, transmisi kebijakan moneter tercermin pada penurunan yield SUN untuk seluruh tenornya. Di pasar saham, indeks harga menunjukkan lonjakan yang membawa IHSG ke level tertinggi sebesar $3.756,9$.

Ke depan, perkembangan ekonomi domestik diperkirakan akan terus membaik. Pertumbuhan ekonomi pada tahun 2011 diperkirakan terakselerasi dan dapat mencapai kisaran 6,0\%-6,5\%. Sementara, pertumbuhan ekonomi untuk tahun 2012 diperkirakan mencapai kisaran 6,1\%-6,6\%. Pertumbuhan tersebut didukung oleh konsumsi rumah tangga yang tetap kuat, investasi yang membaik, serta masih solidnya kinerja ekspor seiring dengan masih kuatnya pertumbuhan di negara mitra dagang, terutama di kawasan Asia. Di sisi harga, Bank Indonesia memprakirakan inflasi di 2011 dapat diarahkan pada kisaran sasarannya, yaitu 5\% $1 \%$ pada tahun 2011 dan 4,5\% $1 \%$ pada tahun 2012. Meskipun demikian, perlu tetap diwaspadai beberapa faktor risiko terhadap pencapaian sasaran inflasi tersebut maupun prospek makroekonomi ke depan, seperti masih tingginya ketidakpastian pemulihan ekonomi global, kenaikan harga komoditas internasional, dan derasnya aliran modal asing masuk yang memicu currency war. Dari sisi domestik, risiko tersebut antara lain terkait dengan meningkatnya ekses likuiditas di sektor keuangan dan kemungkinan gangguan produksi serta distribusi bahan kebutuhan pokok. Sehubungan dengan itu, Bank Indonesia akan menekankan penerapan bauran kebijakan moneter dan makroprudensial, serta memperkuat koordinasi dengan Pemerintah. Beberapa langkah yang sedang dipersiapkan Bank Indonesia untuk mitigasi dampak negatif dari arus masuk modal asing dan sekaligus memperkuat ketahanan sistem perbankan antara lain terkait dengan pengaturan GWM valas dan vostro account (rekening giro Rupiah yang dimiliki oleh non-residen di bank domestik). 
Berdasarkan asesmen dan prospek ekonomi tersebut, Rapat Dewan Gubernur Bank Indonesia pada 3 Desember 2010 memutuskan untuk mempertahankan BI Rate pada level $6,5 \%$ dengan koridor suku bunga sebesar \pm 100 bps. Keputusan tersebut juga mempertimbangkan bahwa tingkat BI Rate 6,5\% masih konsisten dengan pencapaian sasaran inflasi jangka menengah dan dipandang masih kondusif untuk menjaga stabilitas keuangan dan mendorong intermediasi perbankan. Evaluasi terhadap kinerja dan prospek perekonomian secara umum mengarah pada kondisi yang lebih baik. Pertumbuhan ekonomi di tahun 2011 dan tahun 2012 diperkirakan meningkat dengan sumber pertumbuhan yang semakin berimbang. 
halaman ini sengaja dikosongkan 